OPEN ACCESS

Citation: S. Dehury, S. Kumar Dehery, A. Bandhu Das (2021) Karyotype Variation in Eight Cultivars of Indian Dessert Banana (Musa acuminata L.) of Section Eumusa From Odisha, India. Caryologia 74(1): 23-31. doi: 10.36253/ caryologia-597

Received: April 03, 2020

Accepted: February 05, 2021

Published: July 20, 2021

Copyright: (c) 2021 S. Dehury, S. Kumar Dehery, A. Bandhu Das. This is an open access, peer-reviewed article published by Firenze University Press (http://www.fupress.com/caryologia) and distributed under the terms of the Creative Commons Attribution License, which permits unrestricted use, distribution, and reproduction in any medium, provided the original author and source are credited.

Data Availability Statement: All relevant data are within the paper and its Supporting Information files.

Competing Interests: The Author(s) declare(s) no conflict of interest.

ORCID

ABD: $0000-0002-1816-4850$

\section{Karyotype Variation in Eight Cultivars of Indian Dessert Banana (Musa acuminata L.) of Section Eumusa From Odisha, India}

\author{
Shomina Dehury ${ }^{1}$, Subrat Kumar Dehery ${ }^{1}$, Anath Bandhu Das ${ }^{1,2, *}$ \\ ${ }^{1}$ Molecular Cytogenetics Laboratory, Department of Botany, Utkal University, Vani Vihar, \\ Bhubaneswar - 751004, Odisha, India \\ ${ }^{2}$ Centre of Excellence for North East India Studies, (under RUSA 2.0 programme), New \\ Academic Block, Utkal University, Vani Vihar, Bhubaneswar 751004, Odisha, India. \\ *Corresponding author. E-mail: abdas.uubot@gmail.com; a_b_das@hotmail.com; \\ abdas.uubot@utkaluniversity.ac.in
}

\begin{abstract}
Banana (Musa spp.) cultivars especially dessert banana are important cash crop with high market demand all over the world as an integral part of the diet. The need for assessment of cytogenetic characters in Musa cultivars is inevitable as out of thousands of cultivars, cytogenetic characterization of most of them remains unresolved due to difficulties like small chromosome size, diversity in ploidy levels and high cultivar diversity which behave differently to standardized cytogenetic protocols. In this report, somatic chromosome number, detailed karyotype analysis including total chromosome length, volume, form percentage, Interphase Nuclear Volume (INV) were accessed on eight dessert type of Musa accessions from different places of Odisha. All the cultivars studied were found triploid $(2 n=33)$ with a basic chromosome number of $x=11$. The karyotype formulae were assigned to each cultivar by grouping the chromosome according to their shared characteristics. The total chromosome length ranged from $54.95 \mu \mathrm{m}$ in $c v$. Robusta to $81.5 \mu \mathrm{m}$ in $c v$. Kathia with symmetric karyotype in all the studied cultivar. Karyotype formula revealed structural alteration of chromosome with Total Form percentage (TF\%) variation from 35.65\% in $c v$. Amritapani to $41.68 \%$ in $c v$. Patakpura that confirms more number of nearly median constricted chromosome as compared to sub-median chromosome. The total chromosome volume recorded from $10.78 \mu \mathrm{m}^{3}$ in $c v$. Robusta to $15.99 \mu \mathrm{m}^{3}$ in $c v$. Khatia and the INV varied from 1336.44 $\mu \mathrm{m}^{3}$ in $c v$. Dwarf Cavendish to $2048.37 \mu \mathrm{m}^{3}$ in $c v$. Patakpura. The recorded structural variation might be due to differential genome specific condensation of chromosome. Chromosome length and volume found statistically significant among the cultivars.
\end{abstract}

Keywords: chromosome number, genome analysis, ploidy, table-top banana, total

form percentage.

\title{
INTRODUCTION
}

Banana (Musa spp.) belongs to family Musaceae is an important monocot plant used as staple food and cash crop for millions of people that provide 
nutrition and minerals with high calorific value. Cultivated banana are distinguished into dessert or simply called banana and cooking banana or plantain. Banana is cultivated primarily for its highly nutritious fruit beside it has good fiber content obtained from its pseudostem, leaves are used as disposable leaf plates and inflorescence are used for food with high potassium $\left(50.08 \mathrm{mg} \mathrm{g}^{-1}\right)$, calcium (3.78 $\mathrm{mg} \mathrm{l}^{-1}$ ) and phosphorus $\left(3.66 \mathrm{mg} \mathrm{g}^{-1}\right)$ content in dry weight basis (Fingolo et al. 2012).

There are over a thousand domesticated Musa cultivars with a very high genetic diversity (Stover and Simmonds 1987; Perrier et al. 1990). However, due to difficulty of genetic makeup, and sterility of the crop, the development of new varieties through hybridization, mutation or transformation was not very successful in Musa till date (Heslop-Harrisons and Swarzacher 2007). The ploidy level determination of different varieties of Musa is economically important as well as preliminary requisite to facilitate breeding programme from existing genetic diversity of the country for future quantitative and qualitative morphological trait targeted breeding programme. Inter and intra specific hybridization of two wild diploid $(2 n=2 x=22)$ Musa species, Musa acuminata (AA) containing 'A' genome and Musa balbisiana (BB) having ' $\mathrm{B}$ ' genome gave rise to most of the natural banana cultivars with different genomic and ploidy levels i.e. $\mathrm{AA}, \mathrm{AAA}, \mathrm{AAB}, \mathrm{ABB}, \mathrm{AAAB}, \mathrm{AABB}$ and $\mathrm{ABBB}$. The cultivated banana are mostly triploid $(2 n$ $=3 x=33$ ) with a limited varieties/species with diploid or tetraploid constituents. Various cultivars of banana have been originated from independent sources in the wild, so the hybridization events and mutations giving rise to seedless and parthenocarpic characters have occurred many hundreds of times (Simmonds and Shepherd 1955; Heslop-Harrisons and Swarzacher 2007). Where fertile plants occur together, hybridization continues to produce new diversity (Pollefeys et al. 2019) and parental combinations, hence, structural analysis of chromosome is important. Simmonds (1962) considered five plant characteristics that lead to farmers for picking plant vigour, yield, seedlessness, hardiness and fruit quality, the first four of which are related to polyploidy (triploidy). Karyotype analysis provides valuable information related to the mechanisms of genome evolution. Several types of banana out of thousands of cultivars are adapted to the agro-climatic condition of Odisha. Traditionally the economically important cultivars grown in the state are Silk (Patkapura), Poovan (Champa), Cavendish group. Recently, there has been a trend towards the cultivation of Amritpani due to high productivity and consumer acceptability (Maharana et al. 2017). Some of the earlier reports confirmed chromosome number with karyotypes, still data are scanty for different cultivars of banana (Cheesman and Larter 1935; Das and Das 1997). In this study, a detailed karyotype analysis and chromosome number determination has been carried out for further structural analysis of chromosome which is the prerequisite for localization of specific marker gene of interest on to the chromosome through Fluorescence in situ Hybridization (FISH) for genome analysis in eight triploid cultivars of dessert banana cultivated in different parts of Odisha.

\section{MATERIALS AND METHODS}

Eight cultivars of $M$. acuminata namely $c v$. Amritapani, $c v$. Champa, $c v$. Chini Champa, $c v$. Dwarf Cavendish, $c v$. Grand Naine, $c v$. Kathia, $c v$. Patkapura, $c v$. Robusta were collected from different parts of Odisha and maintained in green house of Department of Botany, Utkal University, Bhubaneswar (Table 1). Actively growing root tips were pre-treated in half saturated Para dichlorobenzene $(\mathrm{pDB})$ and aesculin mixture (1:1) for $3 \frac{1}{2} \mathrm{~h}$ at $18^{\circ} \mathrm{C}$ in refrigerator and then fixed in $1: 3$ acetic acid : ethanol overnight at room temperature. Fixed roots were treated in $45 \%$ glacial acetic acid for $15 \mathrm{~min}$. Chromosome staining of fixed roots were done with $2 \%$ aceto-orcein preceded by cold hydrolysis with $5 \mathrm{~N} \mathrm{HCl}$ at $4^{\circ} \mathrm{C}$ for $5 \mathrm{~min}$. Chromosome squash preparation were made using $45 \%$ glacial acetic acid. Squashed slides were observed under Olympus BX-53 microscope and number of chromosomes were calculated. Digital microphotographs were taken in Micro Publisher 5.0 RTV camera observed under Olympus BX-53 microscope for detail analysis of chromosomes and karyotype.

Total chromosome length was estimated by adding the length of all chromosomes in the karyotype and total chromosome volume by applying formula $\pi r^{2} h$, where ' $r$ ' is the radius and ' $h$ ' is the length of the chromosome respectively. Analysis of the chromosome type was conducted according to the classification system of Levan et al. (1964), and that of the karyotype in accordance with the classification standard of Stebbins (1971) modified by Das and Mallick (1993). Form percentage (F $\%$ ) of individual chromosome was calculated.

Interphase Nuclear Volume (INV) was calculated following the formula of sphere i.e. $4 / 3 \pi r^{3}$, where $r$ is the radius of interphase nucleus. Results were analysed from 5-6 well spread metaphasic plates each obtained from the eight Musa cultivars. In order to ascertain the significant differences of different genomic parameters among eight cultivars of banana, if any, the one-way ANOVA test (Sokal and Rohlf 1973) was carried out with Tukey's 
Table 1. List of the eight cultivars of dessert banana (Musa acuminata) germplasm collected from different parts of Odisha.

\begin{tabular}{lccccc}
\hline Cultivar/Accession number & 2n & Genome constitution & Place of collection & District & Latitude/Longitude \\
\hline Amritapani (MU-90) & 33 & AAA & OUAT, Bhubaneswar & Khurda & $20.26^{\circ} \mathrm{N}, 85.81^{\circ} \mathrm{E}$ \\
Champa (MU-107) & 33 & AAB & CHES, Bhubaneswar & Khurda & $20.24^{\circ} \mathrm{N}, 85.78^{\circ} \mathrm{E}$ \\
Chini Champa (MU-133) & 33 & AAB & Tangi-Chaudwar & Cuttack & $20.55^{\circ} \mathrm{N}, 85.99^{\circ} \mathrm{E}$ \\
Dwarf Cavendish (MU-53) & 33 & AAA & RPRC, Bhubaneswar & Khurda & $20.27^{\circ} \mathrm{N}, 85.79^{\circ} \mathrm{E}$ \\
Grand Naine (MU-60) & 33 & AAA & Nimapada & Puri & $20.05^{\circ} \mathrm{N}, 86.00^{\circ} \mathrm{E}$ \\
Kathia (MU-38) & 33 & ABB & Kapilas & Dhenkanal & $20.69^{\circ} \mathrm{N}, 85.74^{\circ} \mathrm{E}$ \\
Patakpura (MU-44) & 33 & AAB & Chandanpur & Puri & $19.88^{\circ} \mathrm{N}, 85.81^{\circ} \mathrm{E}$ \\
Robusta (MU-137) & 33 & AAA & Ramagarh & Cuttack & $20.55^{\circ} \mathrm{N}, 85.98^{\circ} \mathrm{E}$ \\
\hline
\end{tabular}

CHES = Central Horticultural Experimental Station, Bhubaneswar, RPRC Regional Plant Resource Centre, Bhubaneswar, OUAT $=$ Orissa University of Agriculture and Technology, Bhubaneswar.

Honest Significant Difference (HSD) test among the cultivars (Tukey 1949). Correlation co-efficient ' $r$ ' of different chromosomal parameters were made following ' $t$ ' test to compare the significant cytological variation, if any, among the studied cultivated desert banana cultivars.

\section{RESULTS}

Chromosome numbers of all the eight cultivars found to be $2 n=3 x=33$. The chromosome size varied from small to large. All the somatic chromosomes are classified as Type A with comparatively large chromosomes having nearly median (NM) primary and secondary constrictions. Type B with medium to large sized chromosomes having nearly sub-median (NSM) primary constriction and nearly sub terminal (NST) secondary constriction. Type $\mathrm{C}$ with medium size chromosome having nearly median primary constriction $(\mathrm{NM})$ and Type D with small to medium size chromosomes having nearly sub-median (NSM) primary constriction (Fig. 1). Although all the cultivars showed $2 \mathrm{n}=33$ chromosomes, the number variation of different Types of chromosomes in the karyotype formulae were found among the genotypes showing definite differences in their chromosome structure (Figs. 2, 3, Tables 2, Supplementary Table 1).

The total chromosome length ranged from $55.68 \mu \mathrm{m}$ in $c v$. Chini Champa to $81.50 \mu \mathrm{m}$ in $c v$. Kathia. Predominance of nearly median chromosomes is a characteristic

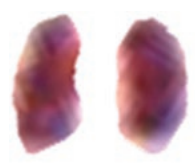

A

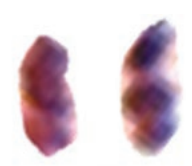

B

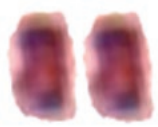

C

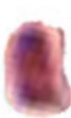

D
Figure 1. Standard karyotype of desert banana (M. acuminata).
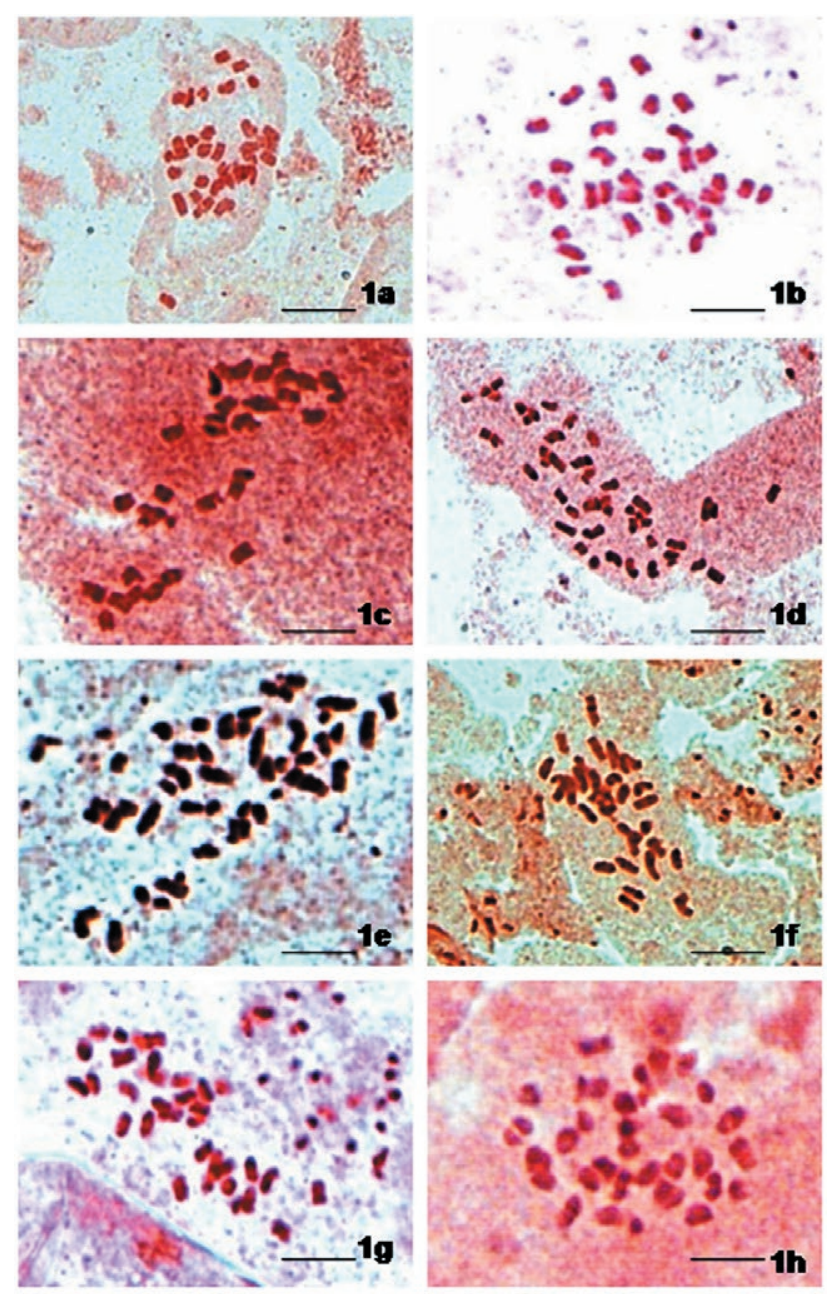

Figure 2a-h. Metaphase plates of eight cultivars of desert banana of Odisha; (a) $c v$. Amritapani, (b) $c v$. Champa, (c) $c v$. Grand Naine, (d) $c v$. Patakpura, (e) $c v$. Dwarf Cavendish, (f) $c v$. Kathia, (g) $c v$. Chini Champa, (h) $c v$. Robusta. Magnification bar $=10 \mu \mathrm{m}$. 


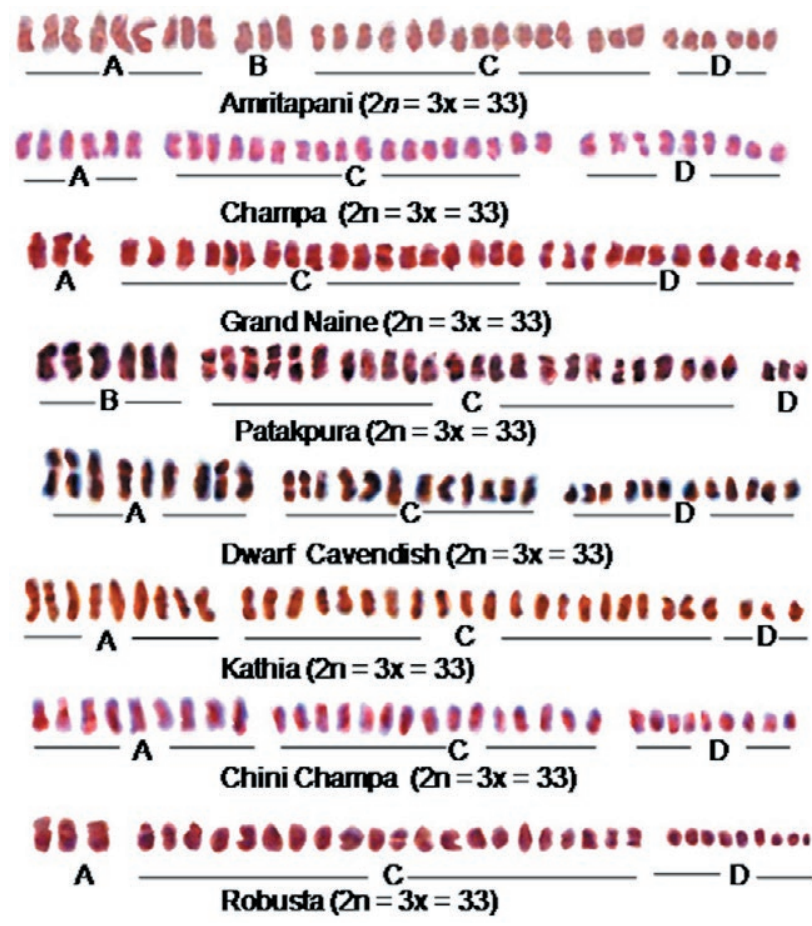

Figure 3. Comparative karyogram of different cultivars of banana of the corresponding metaphase plates.

of the eight studied cultivars in which the TF\% varied from $35.65 \%$ in $c v$. Amritapani to $41.68 \%$ in $c v$. Patakpura. The total chromosome volume was found lowest in $c v$. Robusta $\left(10.78 \mu \mathrm{m}^{3}\right)$ and highest in $c v$. Kathia $\left(15.99 \mu \mathrm{m}^{3}\right)$. The interphase nuclear volume ranged from $1336.44 \mu \mathrm{m}^{3}$ in $c v$. Dwarf Cavendish to $2048.37 \mu \mathrm{m}^{3}$ in cv. Patakpura. Presence of secondary constricted chromosomes varied among cultivars from 12 in $c v$. Amritapani to 3 in $c v$. Grand Naine and Robusta. Karyotype of all the cultivars showed Type A secondary constricted chromosome except $c v$. Patakpura while B Type secondary constricted chromosomes were found in $c v$. Amritapani and $c v$. Patakpura. Other related cytological parameters against each cultivars have been given in Table 2 . Statistical analysis showed significant differences among the cultivars of banana (Table 3). The chromosome length and volume found significantly correlated with a coefficient value of $r=0.99$. However, chromosome length and volume have no such significant correlation with nuclear volume which were -0.287 and -0.288 respectively. Tukey's Honest Significant Difference (HSD) test confirmed that significant differences of total chromosome length and INV were recorded among the studied varieties (data not shown). The chromosome volume varied significantly among the varieties without having any significant variations between $c v$. Chini Champa and $c v$. Champa, $c v$. Dwarf Cavendish and $c v$. Grand Naine, $c v$. Champa, $c v$. Chini Champa and $c v$. Robusta (Table supplementary 2). No significant variation of TF\% was also observed between $c v$. Champa and $c v$. Chini Champa, $c v$. Kathia and $c v$. Champa or $c v$. Chini Champa following Trukey HSD test (Table Supplementary 2).

\section{DISCUSSION}

Cultivated bananas are scientifically interesting, as there is no genetic exchange during reproduction and selection is mostly depends on random mutations (Oladosu et al. 2016). Knowledge of chromosomal characters of the edible cultivars is valuable in order to know banana genetics in details. Edible bananas have $2 n=2 x$ 22,33 or 44 chromosomes for diploid, triploid and tetraploid cultivars respectively (Stover and Simmonds 1987). These cultivars have a wide range of genome permuta-

Table 2. Detail karyotype analysis of the eight banana cultivars with different chromosomal parameters.

\begin{tabular}{|c|c|c|c|c|c|c|c|c|}
\hline Variety & Genome & $\begin{array}{c}\text { Somatic } \\
\text { chromosome } \\
\text { number } \\
(2 \mathrm{n}=3 x)\end{array}$ & Karyotype formula & $\mathrm{NSC}^{+}$ & $\begin{array}{l}\text { Total chromosome } \\
\text { length }(\mu \mathrm{m} \pm \mathrm{SE})\end{array}$ & Total F\% & $\begin{array}{l}\text { Total chromosome } \\
\text { volume }\left(\mu \mathrm{m}^{3} \pm \mathrm{SE}\right)\end{array}$ & $\mathrm{INV}^{++}\left(\mu \mathrm{m}^{3} \pm \mathrm{SE}\right)$ \\
\hline Amritapani & AAA & 33 & $9 A+3 B+15 C+6 D$ & 12 & $75.60 \pm 1.23$ & 35.65 & $14.83 \pm 0.13$ & $1604.66 \pm 3.32$ \\
\hline Champa & $\mathrm{AAB}$ & 33 & $6 \mathrm{~A}+18 \mathrm{C}+9 \mathrm{D}$ & 6 & $58.35 \pm 0.98$ & 39.29 & $11.45 \pm 0.23$ & $1526.50 \pm 5.58$ \\
\hline Chini Champa & $\mathrm{AAB}$ & 33 & $9 A+15 C+9 D$ & 9 & $55.68 \pm 1.45$ & 39.36 & $10.93 \pm 0.34$ & $1352.80 \pm 2.91$ \\
\hline Dwarf Cavendish & AAA & 33 & $9 A+12 C+12 D$ & 9 & $64.52 \pm 0.56$ & 35.82 & $12.66 \pm 0.22$ & $1336.44 \pm 2.74$ \\
\hline Grand Naine & AAA & 33 & $3 \mathrm{~A}+18 \mathrm{C}+12 \mathrm{D}$ & 3 & $63.76 \pm 1.25$ & 38.20 & $12.52 \pm 0.15$ & $1401.46 \pm 4.19$ \\
\hline Kathia & $\mathrm{AAB}$ & 33 & $9 \mathrm{~A}+21 \mathrm{C}+3 \mathrm{D}$ & 9 & $81.50 \pm 2.12$ & 39.10 & $15.99 \pm 0.34$ & $1437.33 \pm 5.16$ \\
\hline Patakpura & $\mathrm{AAB}$ & 33 & $6 B+24 C+3 D$ & 6 & $69.08 \pm 1.34$ & 41.68 & $13.56 \pm 0.16$ & $2048.37 \pm 6.21$ \\
\hline Robusta & AAA & 33 & $3 A+21 C+9 D$ & 3 & $54.95 \pm 0.67$ & 40.18 & $10.78 \pm 0.09$ & $1443.50 \pm 3.17$ \\
\hline
\end{tabular}

${ }^{+}$NSC $=$Number of secondary constricted chromosome; ${ }^{++}$INV = Interphase nuclear volume. 
Table 3. Analysis of variance (ANOVA) of different genomic parameters among the eight cultivars of $M$. acuminata.

\begin{tabular}{lcccc}
\hline Source & DF & SS & MS & F \\
\hline Total chromosome length & & & \\
Between cultivars & 7 & 42.682 & 6.097 & $62.214^{*}$ \\
Within cultivars & 32 & 3.153 & 0.098 & \\
Total & 39 & - & & \\
\hline Total chromosome volume & & & \\
Between cultivars & 7 & 32.127 & 4.589 & $57.362^{*}$ \\
Within cultivars & 32 & 2.563 & 0.080 & \\
Total & 39 & - & & \\
\hline Total Form \% (TF\%) & & & & \\
Between cultivars & 7 & 422.256 & 60.322 & $105.458^{*}$ \\
Within cultivars & 32 & 18.334 & 0.572 & \\
Total & 39 & - & & \\
\hline Total INV & & & & \\
Between cultivars & 7 & 5267.365 & 752.480 & $442.895^{*}$ \\
Within cultivars & 62 & 105.34 & 1.699 & \\
Total & 69 & - & & \\
\hline
\end{tabular}

* Significant at $p \geq 0.001$ level.

DF, degrees of freedom; SS, sum of squares; MS, mean squares; F, variance ratio

tions, including $\mathrm{AA}, \mathrm{AB}, \mathrm{BB}, \mathrm{AAA}, \mathrm{AAB}, \mathrm{ABB}, \mathrm{AAAB}$, ABBB, and AABB. Simmond and Shepherd (1955) differentiated 5 genomic groups viz. $\mathrm{AA}, \mathrm{AB}, \mathrm{AAA}, \mathrm{AAB}$, and $\mathrm{ABB}$ based on the scoring of morphologically diagnostic characters relating to the two wild species $M$. acuminata and M. balbisiana. Within each group, related clones are associated in a subgroup. Cytological studies of Indian species, varieties and cultivars are very scanty except some recent reports (Ghosh et al. 2013; Das et al. 2020; Dehery et al. 2020) and molecular marker analysis (Venkatachalam et al. 2008), though there are many biodiversity hotspots of banana in North East India exists which need to be explored. Banana varieties of Odisha have remarkable popularity in the locality and the cytogenetics of some of the varieties like $c v$. Amritpani, $c v$. Champa, $c v$. Patakpura, $c v$. Kathia has not been extensively covered and reported before.

Musa cultivars were studied and no numerical changes in the somatic chromosomes was observed in the genome that reconfirmed $x=11$ (Table 2). Majority of the chromosomes in each karyotype were found to be in the group of the medium-sized chromosome with median primary constriction. All the 4 Types of chromosomes were present in $c v$. Amritapani whereas rest of cultivars has only 3 Types of chromosomes. Type C and $\mathrm{D}$ were common in all the cultivars with different doses whereas Type B was present in $c v$. Patakpura only and rest cultivars had Type A chromosomes. The dose of nearly median constricted chromosomes were found more in all the cultivars except $c v$. Dwarf Cavendish and cv. Grand Naine that showed 12 Type D chromosomes in the karyotype. Numbers of secondary constricted chromosomes found variable among the cultivars. The total chromosome length varied from $54.95 \mu \mathrm{m}$ in $c v$. Robusta to $81.50 \mu \mathrm{m}$ in $c v$. Kathia and TF\% varied from $35.65 \%$ in $c v$. Amritapani to $41.68 \%$ in $c v$. Patakpura among the studied cultivars. Chromosome volume also found significantly different among the cultivars ranged from $10.78 \mu \mathrm{m}^{3}$ in $c v$. Robusta to $15.99 \mu \mathrm{m}^{3}$ in $c v$. Kathia that might be due to genome specific differential condensation of the heterochromatin and euchromatic region of the chromosomes during metaphase. Thus, variety specific chromosome condensation and volume variation might be an indication of genome size variation which need further experimentation.

Differences in chromosome length or chromosome volume may be due to differential condensation and spiralization of the chromosome arms. In addition, the species-specific compaction of DNA threads along with nucleosomes with altered non-histone proteins (Das and Mallick 1989). The alteration in the TF\% might be due to chromosomal alteration due to break and reunion of the chromosome arms in early stages of evolution in the genome rather than the methodological defect of chromosome squash preparation. Furthermore, translocation mediated structural alteration played a crucial role in chromosome evolution (Lysak et al. 2006; Luiz et al. 2009) besides heteromorphicity in centromeriac position among the chromosomes of Allium localizing GC- and AT-rich repeats by CMA- and DAPI-banding patterns (Mahbub et al. 2014). The dissymmetrical coefficient of the karyotype through FISH in Hibiscus mutabilis f. mutabilis, L. confirms relatively advanced type over plants with symmetrical chromosomes of the primitive type with respect to evolution (Li et al. 2015). Duplication of chromosomes or translocation between the chromosomes with or without secondary constrictions at a very early stage of evolution might be the reason for the structural alteration of the chromosome morphology as well as the variation of secondary constricted chromosomes in the above cultivars (Das and Das 1994; Rai et al. 1997; Ghosh et al. 2013; Das et al. 2015, 2020; Dehery et al. 2020).

Cultivars with reported AAA genome like $c v$. Amritapani, $c v$. Dwarf Cavendish, $c v$. Grand Naine and $c v$. Robusta found to have Type A, C and D found common with 12 numbers of Type D chromosomes each of $c v$. Dwarf Cavendish and $c v$. Grand Naine and 3 Type A each of $c v$. Grand Naine and $c v$. Robusta showing interrelationships among them having close affin- 
ity which need further investigation applying different DNA markers. However, $c v$. Amritapani had 9 Type A with 3 numbers of Type B of chromosomes with less numbers of Type D chromosomes i.e. small sized submedian primary constriction. Less number of secondary constricted chromosomes in $c v$. Grand Naine and $c v$. Robusta genome might be more stable with less chances of chromosomal alteration due to break and reunion of the chromosomes in karyotypes during micro-evolution. But cv. Amritapani differs from others with the presence of more number of secondary constriction and the karyotype is comparatively more fragile and karyotype asymmetry analysis might through some light on karyotype evolution in banana (Dehery et al. 2020).

Cultivars recorded $\mathrm{AAB}$ genome types like $c v$. Champa, $c v$. Cheni Champa, $c v$. Patakpura and $c v$. Kathia with 3 types of chromosomes where Type $\mathrm{C}$ and $\mathrm{D}$ were common in all the 4 cultivars. In this genotypic group $c v$. Patakpura showed 6 Type of B chromosomes. In contrary, $c v$. Chini Champa and $c v$. Kathia showed each of 9 Type A chromosomes that with less number of Type D chromosomes in $c v$. Kathia than $c v$. Chini Champa. Evidently, all the members of $\mathrm{AAB}$ group might close genetic relationship and decrease of median constricted Type $\mathrm{C}$ chromosomes and increase of Type $\mathrm{D}$ chromosomes in $c v$. Champa and $c v$. Chini Champa clearly indicates their close genetic affinity in this genotypic group.

High TF\% in all the cultivars except $c v$. Amritapani indicate the alteration of chromosome structure in the genome. These factors indicate greater genome stability conferring resistance to the cultivars against biotic or abiotic environmental stresses which is a characteristic feature of cultivars with $\mathrm{B}$ genome that need to confirm in future by fluorescent in situ hybridization (FISH) or genomic in situ hybridization (GISH) as shown in other cultivars of banana using BAC clones (D'Hont et al. 2000; Doležel et al. 2004; D'Hont 2005; Jeridi et al. 2011).

Chromosomes with median, nearly median, submedian or nearly sub-median position of centromere are prevalent in karyotypes reported in this work. Significant variations in the chromosome were not noted while analyzing the karyotypes of the eight cultivars studied as the eight triploid varieties known to have been derived from hybridization of the wild species have almost similar combinations of chromosomes with median and sub-median constrictions, with minute variations. Although a significant variation in genome length, volume and INV was recorded (Table 3). The small size of the chromosomes and the difficulty in obtaining a sufficient number of cells containing metaphase chromosomes makes it tedious rather difficult for the studies of the karyotype of bananas and plantain represented by many cultivars and subgroups in nature need to be analyzed with FISH applying genome specific probes of transposable element for evolution among the cultivars. A positive high correlation was noted between chromosome length and chromosome volume $(r=0.99)$ that might be due to genome specific genetic control of chromosome condensation and packaging of histone protein. Evolution of karyotype in species of identical chromosome number belongs to a distinct phylogenetic group is a long-standing issue that could be addressed by comparative chromosome painting to reconstruct karyotype evolution as evident in Crucifer species of Brassicaceae (Mandáková and Lysak 2008) and Orchidaceae (Medeiros-Neto et al. 2017).

\section{ACKNOWLEDGMENTS}

The authors are thankful to the Head of the Botany, Utkal University for providing administrative and microscopic facilities developed under DSR-III, University Grant Commission, and FIST programme, Govt. of India to carry out the research. ABD acknowledge the financial assistance received from Council of Scientific and Industrial Research, Human Resource Development Group, Sanction No. 21(1107)/20/EMR-II), Government of India, New Delhi.

\section{FUNDING}

This work was supported financially by the Department of Biotechnology, Ministry of Science and Technology, Government of India [Project No DBT-NER/ AGRI/33/2016 (Group-I, Application No. 02)] is highly acknowledged.

\section{REFERENCES}

Cheesman EE, Larter LNH. 1935. Genetical and cytological studies of Musa. III. Chromosome numbers in Musaceae. J. Genetics 30: 31-52.

D'Hont A. 2005. Unraveling the genome structure of polyploids using FISH and GISH; examples of sugarcane and banana. Cytogenet. Genome Res. 109: 27-33.

D'Hont A, Paget-Goy A, Escoute J, Carreel F. 2000. The interspecific genome structure of cultivated banana, Musa spp. revealed by genomic DNA in situ hybridization. Theor. Appl. Genet. 100: 177-183.

Das AB, Das A, Pradhan C, Naskar SK. 2015. Genotypic variations of ten Indian cultivars of Colocasia esculen- 
ta var. antiquorom Schott. evident by chromosomal and RAPD markers. Caryologia 68: 44-54.

Das AB, Mallick R. 1989. Varietal difference in 4C DNA content and chromosome characteristic of Coriandrum sativum L. Cytologia 54: 609-616.

Das AB, Mallick R. 1993. Karyotype diversity and interspecific 4C DNA variation in Bupleurum. Biol. Plantarum 35: 355-363.

Das AB, Das P. 1994. Estimation of 4C DNA content and karyotype analysis in edible varieties of banana (Musa acuminata). Cytobios 78: 213-220.

Das AB, Das P. 1997. Estimation of nuclear DNA content and karyotype analysis in nine cultivars of Musa acuminata. Cytobios 90:181-192.

Das AB, Dehery SK, Kiran, Jena SN, Sinha RK. 2020. A new seeded diploid accession of Musa laterita of Section Rhodochlamys from Gangtok, Sikkim, India with morphology, chromosome number and genome size. Cytologia 85(1):63-69.

Dehery S, Panda E, Saha PR, Sinha RK, Das AB. 2020. Chromosome diversity and karyotype asymmetry analysis in four cultivated triploid and three diploid wild genotypes of Musa from North-East India. Nucleus (2020). https://doi.org/10.1007/s13237-020-00334-z

Doležel J, Valárik M, Vrána J, Lysák MA, Hřibová E, Batroš J, Gasmanová N, Doleželova M, Šafář J, Šimková H. 2004. Molecular cytogenetics and cytometry of bananas (Musa Spp.). In: Jain, S. M. and Swennen, R. (eds.). Banana Improvement: Cellular, Molecular Biology, and Induced Mutations, Science Publishers, Inc. Enfield, Plymouth, UK, pp. 229-244.

Fingolo CE, Braga J, Vieira A, Moura MRL, Auxiliadora M, Kaplan C. 2012. The natural impact of banana inflorescences (Musa acuminata) on human nutrition, Anais da Academia Brasilerira de Ciências 84: 891-898.

Ghosh S, Das A, Ghorai A, Jha TB. 2013. Comparative kayomorphology of edible Musa cultivars of West Bengal, Caryologia 66: 243-250.

Heslop-Harrisons JS, Swarzacher T. 2007. Domestication, genomics and the future for banana. Ann Bot 100:1073-1084.

Jeridi M, Bakry F, Escoute J, Fondi E, Carreel F, Ferchichi A, D'Hont A, Rodier-Goud M. 2011. Homoeologous chromosome pairing between the $\mathrm{A}$ and $\mathrm{B}$ genomes of Musa spp. revealed by genomic in situ hybridization. Ann. Bot. 108: 975-981.

Levan A, Fredya K, Sandberg A. 1964. Nomenclatyure for centromeric position on chromosome. Heridity 52: 201-220.

Li Y, Zhang Z, Wu W, Miao S, Chang J. 2015. Chromosome and karyotype analysis of Hibiscus mutabilis $\mathrm{f}$. mutabilis. Front. Life Sci. 8:300-304.
Maharana K, Beura S, Munsi PS. 2017. A Fast Protocol for in vitro cloning of banana (Musa acuminata) $\mathrm{cv}$. Amritpani. Int. J. Curr. Microbiol. App. Sci. 6: 586-594.

Mahbub M, Sultana SS, Habib MA, Alam SS. 2014. Karyotype and RAPD Analysis of Allium tuberosum Rottl. Ex Spreng. and three specimens of Allium cepa L. Cytologia 79: 409 - 418.

Mandáková T, Lysak MA. 2008. Chromosomal phylogeny and karyotype revolution in $\mathrm{x}=7$ Crucifer species (Brassicaceae). Plant Cell 20: 2559 - 2570.

Medeiros-Neto E, Nollet F, Moraes AP, Felix LP. 2017. Intrachromosomal karyotype asymmetry in Orchidaceae. Genet. Mol. Biol. 40: 610-619.

Oladosu Y, Rafii MY, Abdullah N, Hussin G, Ramli A, Rahim HA, Miah G, Usman M. 2016. Principle and application of plant mutagenesis in crop improvement: a review. Biotechnol. Biotechnol. Equip. 30:1-16.

Perrier X, Tézenas du Montcel H. 1990. Musaid : a computerized determination system. In: Jarret, R. (ed.). Proceedings of Identification of Genetic Diversity in the genus Musa, Los Banos (PHL), 1988/09/05-10. Identification of Genetic diversity in the genus Musa: Proceedings of an International Workshop. INIBAP, Montpellier, France. p. 76-91.

Pollefeys P, Sharrock S, Arnaud E. 2019. Preliminary analysis of the literature on the distribution of wild Musa species using MGIS and DIVA-GIS, 2004 Montpellier, France INIBAP http://bananas.bioversityinternational.org/files/files/pdf/publications/wildspecies_pollefeys.pdf. Accessed August 2019.

Rai S, Das AB, Das P. 1997. Estimation of 4C DNA and karyotype analysis in ginger (Zingiber officinale Rosc) - I. Cytologia 62: 133-141.

Simmonds NW. 1962. Evolution of the bananas. London Longmans, Green \& Co.

Simmonds NW, Shepherd K. 1955. The taxonomy and origin of the cultivated banana. J. Linn. Soc. Bot. 55: 302-312.

Sokal RR, Rohlf FJ. 1973. Introduction to Biostatistics. W.H. Freeman \& Company, New York. pp. 208-223.

Stebbins GL. 1971. Chromosomal evolution in higher plants. London: Edward Arnold.

Stover RH, Simmonds NW 1987. Classification of banana cultivars. In: Stover RH and Simmonds NW (ed.) Bananas, 3rd edn. Wiley, New York, pp.97-103.

Tukey J. 1949. Comparing individual means in the analysis of variance. Biometrics. 5 (2): 99-114.

Venkatachalam L, Sreedhar RV, Bhagyalakshmi N 2008. The use of genetic markers for detecting DNA polymorphism, genotype identification and phylogenetic relationships among banana cultivars. Mol Phylogenet Evol 47:974-985. 
Supplementary Table 1. Detailed karyotype analysis of the eight dessert banana cultivars.

\begin{tabular}{|c|c|c|c|c|c|}
\hline $\begin{array}{l}\text { Chromosome } \\
\text { Types }\end{array}$ & $\begin{array}{l}\text { Number of } \\
\text { chromosomes }\end{array}$ & $\begin{array}{c}\text { Total } \\
\text { chromosome } \\
\text { length }(\mu \mathrm{m})\end{array}$ & $\begin{array}{l}\text { Length of } \\
\text { short arm } \\
\quad(\mu \mathrm{m})\end{array}$ & $\mathrm{F} \%$ & Nature of constriction \\
\hline
\end{tabular}

\section{M. acuminata cv. Amritapani}

B $\quad 3 \quad 7.48$

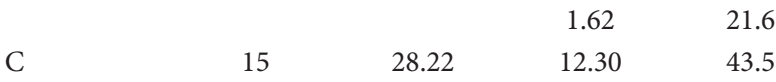

$\begin{array}{lllll}\mathrm{D} & 6 & 11.67 & 3.81 & 34.6\end{array}$

34.06 Comparatively large chromo-some with NM primary and NSM

27.71 secondary constrictions.

29.27 NSM primary and secondary constriction.

2. M. acuminata cv. Champa

$\begin{array}{llll}\text { A } & 6 & 11.88 & 4.15\end{array}$

$\begin{array}{lllll}\text { C } & 18 & 24.77 & 11.02 & 44.48\end{array}$

34.93 Comparatively large chromo-some having NM primary and NSM

Medium size chromosomes with NM primary constriction.

4.64 Small size chromosomes with NSM primary constriction.

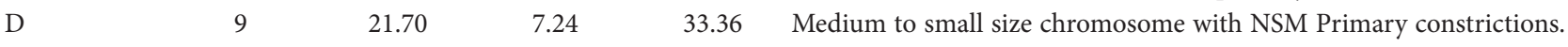

3. M. acuminata cv. Chini Champa

\begin{tabular}{|c|c|c|c|c|c|}
\hline A & 9 & 16.71 & $\begin{array}{l}5.69 \\
4.60\end{array}$ & $\begin{array}{l}34.04 \\
27.52\end{array}$ & $\begin{array}{l}\text { Comparatively large chromo-some having NM primary and NSM } \\
\text { secondary constrictions. }\end{array}$ \\
\hline $\mathrm{C}$ & 15 & 25.67 & 11.55 & 45.0 & Medium size chromosomes with NM primary constriction. \\
\hline $\mathrm{D}$ & 9 & 13.3 & 4.48 & 33.7 & Medium to small size chromo-Some with NSM primary constrictions. \\
\hline
\end{tabular}

\section{M. acuminata cv. Dwarf Cavendish}

\begin{tabular}{|c|c|c|c|c|c|}
\hline A & 9 & 22.85 & $\begin{array}{l}8.83 \\
6.20\end{array}$ & $\begin{array}{l}36.49 \\
27.13\end{array}$ & $\begin{array}{l}\text { Comparatively large chromo-some having NM primary and NSM } \\
\text { secondary constrictions. }\end{array}$ \\
\hline $\mathrm{C}$ & 12 & 25.58 & 10.38 & 40.57 & Medium size chromosomes with NM primary constriction. \\
\hline $\mathrm{D}$ & 12 & 14.84 & 5.10 & 34.36 & Medium size chromosomes with NSM primary constrictions. \\
\hline \multicolumn{6}{|c|}{ 5. M. acuminata cv. Grand Naine } \\
\hline \multirow[t]{2}{*}{ A } & 3 & 6.81 & 2.58 & 37.88 & \multirow{2}{*}{$\begin{array}{l}\text { Comparatively large chromo-some having NM primary and NSM } \\
\text { secondary constrictions respectively. }\end{array}$} \\
\hline & & & 1.95 & 27.60 & \\
\hline $\mathrm{C}$ & 18 & 33.59 & 14.81 & 44.09 & Medium size chromosomes with NM primary constriction. \\
\hline $\mathrm{D}$ & 12 & 23.36 & 7.29 & 31.20 & Medium size chromosomes with NSM primary constrictions. \\
\hline \multicolumn{6}{|c|}{ 6. M. acuminata cv. Kathia } \\
\hline \multirow[t]{2}{*}{ A } & \multirow[t]{2}{*}{9} & \multirow[t]{2}{*}{24.68} & 8.99 & 36.42 & \multirow{2}{*}{$\begin{array}{l}\text { Comparatively large chromo-some having NM primary and NSM } \\
\text { secondary constrictions. }\end{array}$} \\
\hline & & & 7.06 & 28.60 & \\
\hline $\mathrm{C}$ & 21 & 45.6 & 19.79 & 43.40 & Medium size chromosomes with NM primary constriction. \\
\hline $\mathrm{D}$ & 3 & 11.21 & 3.72 & 33.18 & Medium size chromosomes with NSM primary constrictions. \\
\hline \multicolumn{6}{|c|}{ 7. M. acuminata cv. Patakpura } \\
\hline \multirow[t]{2}{*}{ B } & \multirow[t]{2}{*}{6} & \multirow[t]{2}{*}{14.55} & 4.17 & 28.65 & \multirow{2}{*}{$\begin{array}{l}\text { Comparatively large chromo-somes with NSM primary and } \\
\text { secondary constriction. }\end{array}$} \\
\hline & & & 3.61 & 24.81 & \\
\hline $\mathrm{C}$ & 24 & 47.76 & 21.03 & 44.03 & Medium size chromosomes with NM primary constriction. \\
\hline $\mathrm{D}$ & 3 & 6.77 & 2.46 & 36.33 & Medium size chromosomes with NSM primary constrictions. \\
\hline \multicolumn{6}{|c|}{ 8. M. acuminata cv. Robusta } \\
\hline \multirow[t]{2}{*}{ A } & \multirow[t]{2}{*}{3} & \multirow[t]{2}{*}{6.46} & 1.9 & 29.41 & \multirow{2}{*}{$\begin{array}{l}\text { Comparatively large chromo-some having NSM primary and } \\
\text { secondary constrictions. }\end{array}$} \\
\hline & & & 1.5 & 23.22 & \\
\hline $\mathrm{C}$ & 21 & 32.02 & 14.6 & 45.6 & Medium size chromosomes with NM primary constriction. \\
\hline $\mathrm{D}$ & 9 & 16.47 & 5.22 & 31.70 & Medium size chromosomes with NSM primary constrictions. \\
\hline
\end{tabular}

$\mathrm{NM}=$ Nearly median, NSM $=$ Nearly sub median, NST $=$ nearly sub terminal. 
Supplementary Table 2. Mean difference of different cytological parameters among different varieties of M. acuminata and their significant level after Tuky's test.

\begin{tabular}{|c|c|c|c|c|c|c|c|}
\hline & Champa & Chini Champa & Dwarf Cavendish & Grand Naine & Kathia & Patakpura & Robusta \\
\hline \multicolumn{8}{|c|}{ Chromosome length } \\
\hline Amritapani & $17.25^{\star}$ & $19.92^{*}$ & $11.08^{\star}$ & $11.84^{*}$ & $5.9^{*}$ & $6.52^{\star}$ & $20.65^{\star}$ \\
\hline Champa & & $2.67^{\star}$ & $6.17^{\star}$ & $5.41^{\star}$ & $23.15^{*}$ & $10.73^{*}$ & $3.4^{*}$ \\
\hline Chini Champa & & & $8.84^{*}$ & $8.08^{\star}$ & $25.82^{*}$ & $13.4^{*}$ & $0.73^{\star}$ \\
\hline Dwarf Cavendish & & & & $0.76^{\star}$ & $16.98^{*}$ & $4.56^{*}$ & $9.57^{\star}$ \\
\hline Grand Naine & & & & & $17.74^{*}$ & $5.32^{*}$ & $8.81^{\star}$ \\
\hline Kathia & & & & & & $12.42^{*}$ & $26.55^{\star}$ \\
\hline Patakpura & & & & & & & $14.13^{*}$ \\
\hline \multicolumn{8}{|c|}{ Chromosome volume } \\
\hline Amritapani & $3.38^{\star}$ & $3.9^{*}$ & $2.17 \mathrm{~ns}$ & $2.31 \mathrm{~ns}$ & $1.16 \mathrm{~ns}$ & $1.27 \mathrm{~ns}$ & $4.05^{\star}$ \\
\hline Champa & & $0.52 \mathrm{~ns}$ & $1.21 \mathrm{~ns}$ & $1.07 \mathrm{~ns}$ & $4.54^{\star}$ & $2.11 \mathrm{~ns}$ & $0.67 \mathrm{~ns}$ \\
\hline Chini Champa & & & $1.73 \mathrm{~ns}$ & $1.59 \mathrm{~ns}$ & $5.06^{*}$ & $2.63 \mathrm{~ns}$ & $0.15 \mathrm{~ns}$ \\
\hline Dwarf Cavendish & & & & $0.14 \mathrm{~ns}$ & $3.33^{*}$ & $0.9 \mathrm{~ns}$ & $1.88 \mathrm{~ns}$ \\
\hline Grand Naine & & & & & $3.47^{\star}$ & $1.04 \mathrm{~ns}$ & $1.74 \mathrm{~ns}$ \\
\hline Kathia & & & & & & $2.43 \mathrm{~ns}$ & $5.21^{\star}$ \\
\hline Patakpura & & & & & & & $2.78^{*}$ \\
\hline \multicolumn{8}{|c|}{ Total Form Percentage (TF\%) } \\
\hline Amritapani & $3.64^{*}$ & $3.71^{*}$ & $0.17^{\star}$ & $2.55^{\star}$ & $3.45^{*}$ & $6.03^{*}$ & $4.53^{*}$ \\
\hline Champa & & $0.07 \mathrm{~ns}$ & $3.47^{\star}$ & $1.09^{*}$ & $0.19 \mathrm{~ns}$ & $2.39^{*}$ & $0.89^{*}$ \\
\hline Chini Champa & & & $3.54^{\star}$ & $1.16^{*}$ & $0.26 \mathrm{~ns}$ & $2.32^{\star}$ & $0.82^{*}$ \\
\hline Dwarf Cavendish & & & & $2.38^{*}$ & $3.28^{*}$ & $5.86^{*}$ & $4.36^{\star}$ \\
\hline Grand Naine & & & & & $0.90^{\star}$ & $3.48^{\star}$ & $1.98^{\star}$ \\
\hline Kathia & & & & & & $2.58^{\star}$ & $1.08^{\star}$ \\
\hline Patakpura & & & & & & & $1.50^{*}$ \\
\hline \multicolumn{8}{|c|}{ Interphase Nuclear Volume (INV) } \\
\hline Amritapani & $78.16^{*}$ & $251.86^{\star}$ & $268.22^{\star}$ & $203.2^{\star}$ & $167.33^{*}$ & $443.71^{\star}$ & $161.16^{*}$ \\
\hline Champa & & $173.7^{\star}$ & $190.06^{*}$ & $125.04^{*}$ & $89.17^{*}$ & $521.87^{\star}$ & $83.0^{*}$ \\
\hline Chini Champa & & & $16.36^{*}$ & $48.66^{* *}$ & $84.53^{*}$ & $695.57^{\star}$ & $90.7^{\star}$ \\
\hline Dwarf Cavendish & & & & $65.02^{\star}$ & $100.89^{*}$ & $711.93^{\star}$ & $107.06^{*}$ \\
\hline Grand Naine & & & & & $35.87^{*}$ & $646.91^{*}$ & $42.04^{*}$ \\
\hline Kathia & & & & & & 611.04 & $6.17^{\star}$ \\
\hline Patakpura & & & & & & & $604.87^{\star}$ \\
\hline
\end{tabular}

* Significant at $p \geq 0.001$ level. 